\title{
Urban sprawl, commuting and travel energy consumption
}

Q2 Anne-Françoise Marique

Research engineer, LEMA, University of Liège, Liège, Belgium

Q3 Sebastien Dujardin

Researcher, Lepur, University of Liège, Liège, Belgium

Jacques Teller PhD

Professor in Architecture and Urban Planning, Director of LEMA, University of

Liège, Liège, Belgium

\section{Sigrid Reiter PhD}

Professor in Architecture and Urban Planning, LEMA, University of Liège, Liège, Belgium

Commuting to and from dense urban centres is often believed to be more energy efficient than commuting from more suburban areas. However, quantitative evidence is lacking. In this context, this paper investigates the interactions between the spatial structure of the territory and transport energy consumption for commuting. Based on empirical surveys carried out every 10 years in Belgium, a quantitative method was developed and applied to assess energy efficiency of home-to-work and home-to-school trips. The main findings highlight that urban planning acts on travel energy consumption for commuting and that major cities present low energy consumption. However, a local-scale approach is useful for refining these observations, and this approach highlights the existence of secondary suburban and rural cores that are also characterised by low transport energy consumption. In this respect, the distance from home to a destination is paramount, whereas the mode of transport used has a lower impact. The method is parameterised and reproducible in other territories.

\section{Introduction}

The problems associated with energy use, such as global climate change caused by the release of carbon dioxide and other greenhouse gases (GHGs), are receiving increasingly more attention (Glicksman, 2007). In the transportation sector, which represents approximately $32 \%$ of the final energy used in Europe (European Commission, 2008), increases in energy consumption and GHG emissions due to commuting by car is of particular concern. The rise in individual mobility is mainly attributed to the physical expansion of urban areas, commonly referred to as urban sprawl. Due to the combination of rapidly declining transport costs and increasing travel speed (Ewing, 1994), the accessibility of outlying areas and vehicle miles of travel per capita have increased substantially over the recent past and have favoured the development of suburban neighbourhoods. Sprawl is believed to be facilitated by car ownership and use and also to contribute to it, in a positive feedback loop that reinforces both low-density development and motorisation (Gilbert and Perl, 2008). The environmental impacts of urban sprawl have been studied in depth, and urban sprawl has been identified as a major issue for sustainable development (European Environment Agency, 2006). Although it is often defined in terms of 'undesirable' land-use patterns (Ewing, 1994; Urban Task Force, 1999) in the scientific field, sprawl often induces lower land prices and more affordable housing (Gordon and Richardson, 1997). Low-density developments also mean more room and a higher standard of living for numerous households, and constitute one of the preferred living accommodations (Berry and Okulicz-Kozaryn, 2009; Couch and Karecha, 2006; Gordon and Richardson, 1997; Howley, 2009).

Although it is usually argued that more compact urban forms would significantly reduce energy consumption both in the building and transportation sectors (Ewing et al., 2008; Gillham, 2002; Newman and Kenworthy, 1999; Steemers 2003), suburban developments continue to grow. An evaluation of the sustainability of suburban neighbourhoods is necessary, and such an evaluation requires appropriate methods and tools, especially regarding private transport. Transport energy consumption is rarely taken into account when the sustainability of suburban structures is studied, even in cases in which sharp fluctuations in oil prices and reduction efforts in GHG emissions play an important role in ongoing discussions and policies. Various scientific articles have already studied the relationships between transport energy consumption and building density. Based on data from 32 large cities located all over the world, Newman and Kenworthy (1999) have highlighted a strong inverse relationship between urban density and transport consumption. However, Breheny and Gordon (1997) demonstrated that the density coefficient and its statistical significance decrease when petrol prices and income are included as explanatory variables. Different studies also underline the importance of the price of travel and the influence of socioeconomic factors 
on transport behaviours (Boarnet and Crane, 2001; Van de Coevering and Schwanen, 2006). Souche (2010), studying 10

Q4 cities around the world (through the IUTP database), showed that the two variables that are most statistically significant for transport energy consumption assessment are transport costs and urban density. On the basis of various case studies, Ewing and Cervero (2001) evaluated quantitatively the impact of urban density, local diversity, local design and regional accessibility on mean vehicle travel distances. The elasticity was evaluated at -0.05 for urban density, -0.05 for local diversity, -0.03 for local design and -0.2 for regional destination accessibility. It means that if the density of a district is multiplied by two, private car commutes are only reduced by $5 \%$. Note that the impact of destination accessibility is larger than the three others parameters combined, suggesting that areas of high accessibility, such as city centres, may produce substantially lower transport energy consumption than dense and mixed developments in less accessible areas. Ewing et al. (2008) found that the most compact metropolitan areas in the USA generate $35 \%$ less mean vehicle travel distances per capita than the most sprawling metropolitan areas. Ewing and Cervero (2010) showed that a $10 \%$ reduction in distance to downtown reduces mean vehicle travel by $2.2 \%$ and a $10 \%$ increase in nearby jobs reduces mean vehicle travel by $2 \%$. Finally, more compact developments (including density, functional mix and transit accessibility) can reduce mean vehicle travel per capita by 25-30\% (Ewing and Cervero, 2010).

Finally, the issue of scale should also be addressed as existing research and studies mainly consider large and dense urban areas (Banister, 1992; Ewing and Cervero, 2001; Newman and Kenworthy, 1999) that do not exist in Belgium (with the exception of the city of Brussels). Owens (1986), for example, found that different characteristics of the spatial structure are important in terms of the energy efficiency across different scales. Regarding the impact of land use on transportation, Van Wee (2002) distinguished several spatial levels: the direct surroundings of the dwellings, the neighbourhood, the town/ city, the region, a subset of a country, the entire country and the international scale. In 2008, the World Energy Outlook recognised that the factors that were influencing city energy use were different from the energy use profiles of the countries the cities were in as a whole, and suggested that, in industrialised countries, the energy use per capita of city residents tends to be lower than the national average (OECD and IEA, 2008). Nonetheless, the issue of geographical scale is often neglected in discussions about the compact city and transport energy savings that too often 'elide scale' (Neuman, 2005).

The aim of this paper is to analyse the role of the spatial structure of the territory, and in particular the impact of urban sprawl, on transport energy consumption at the regional and local scale. Urban structure is understood here as the system defined by three main elements: the location of work places and services (commercial, education, leisure, etc.), the spatial distribution of population according to the place of residence, and infrastructures (transport and technical networks). The aim of this exercise is to understand and address the sustainability of transport in territories and highlight parameters of paramount importance. This study focuses on home-to-work and home-to-school commuting. Although home-to-work and home-to-school trips are becoming less meaningful in daily travel patterns in the west due to the dramatic growth in other activities (Graham, 2000; Lavadinho and Lensel, 2010; Pisarski, 2006), they have more structural power than other forms of travel because they are systematic and repetitive (Dujardin et al., 2011). Among all the residential commuting within the Walloon region of Belgium, home-to-work and home-to-school trips account, respectively, for 30\% and $17 \%$ of trips and for $45 \%$ and $9 \%$ of the total distance travelled (Hubert, 2004).

In section 2, the paper presents the study area and the quantitative method used to assess the transport system in Belgium. Three indices (the energy performance index, the modal share index and the distance travelled index) are developed and mapped in section 3 to investigate the interdependences between the urban structure of the territory, urban sprawl and travel energy consumption for commuting at several territorial scales. In sections 4, 5 and 6, the difference in energy performance between home-to-work and home-to-school trips, the evolution of the performance index between 1991 and 2001 and the most influential parameters are presented and discussed. Section 7 discusses the limitations of the method and section 8 summarises our main findings.

\section{Study area and methods}

\subsection{Study area: the Walloon region of Belgium and urban sprawl}

Urban sprawl is particularly familiar in the Walloon region of Belgium where numerous suburban residential neighbourhoods have been developed in recent decades. These neighbourhoods are characterised mainly by low-density residential housing, the mono-functionality of the developments (functionality concerns mainly housing but also commercial or industrial developments), the discontinuity with traditional urban cores and the great dependence on cars (Halleux et al., 2002). Such suburban neighbourhoods are often developed far from city centres where land prices are lower but where public transportation is generally less available. These developments have thus created further spatial separation of activities, which results in an increase in travel distances and transport energy consumption (da Silva et al., 2007). This phenomenon is familiar in Belgium and there are numerous studies dealing with it. However, it remains difficult to represent sprawl spatially. 


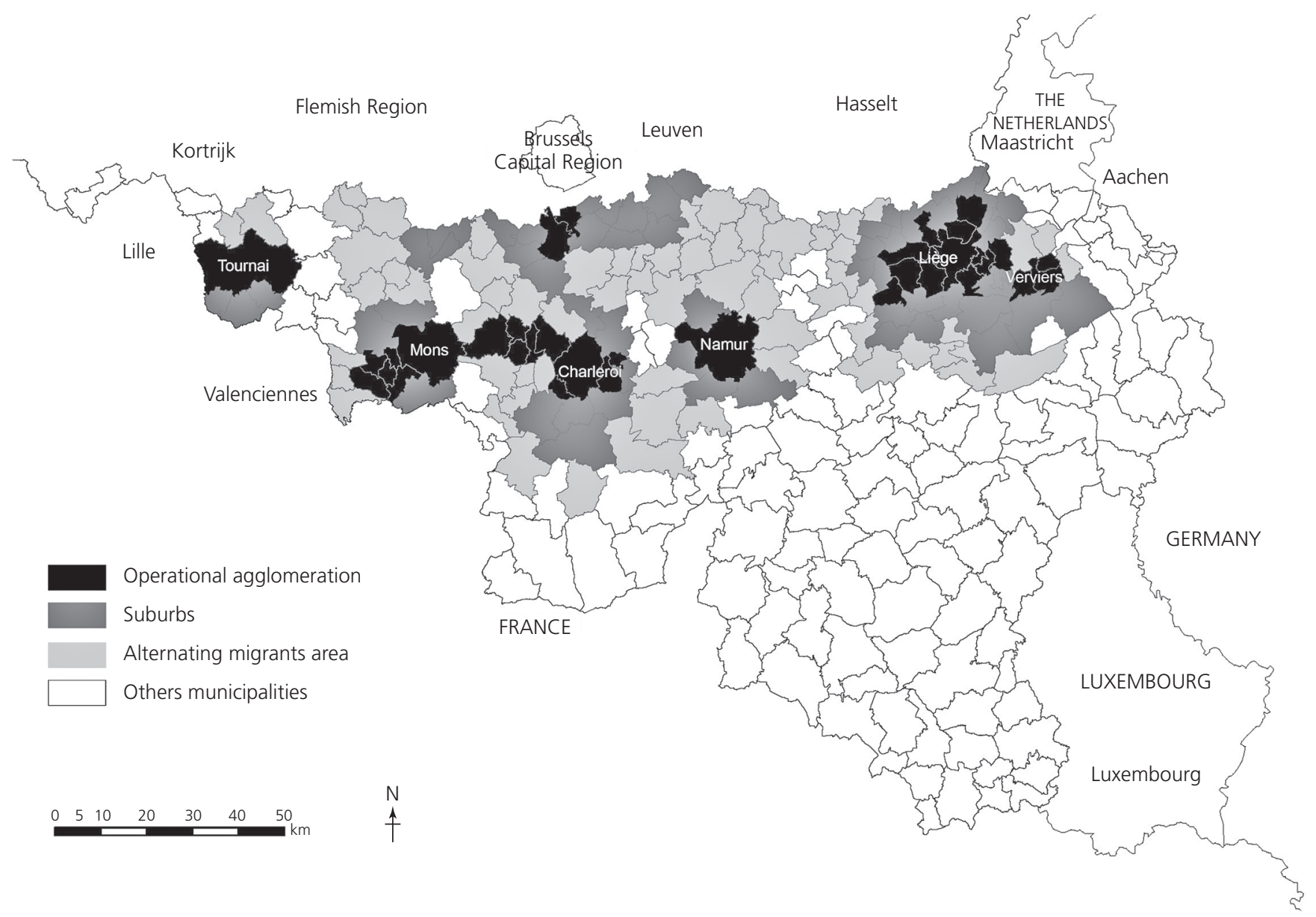

Figure 1. Urban type classification (Sporck et al., 1985; Van der Haegen et al., 1996)

The authors propose, in this paper, to adopt the definition captured by Van der Haegen and Van Hecke's urban type classification (Sporck et al., 1985; Van der Haegen et al., 1996) (Figure 1). Based on qualitative as well as quantitative data, this classification ranks the 589 Belgian municipalities (262 for the Walloon region) in four categories according to their level of functional urbanisation, morphological and functional criteria. The 'operational agglomeration' was based on the morphological agglomeration, or the density of urban cores. Its limits were determined by the continuity of the building stock and adapted to administrative borders. The 'suburbs' were the first suburban area of a city. The density of the population remains less than 500 inhabitants $/ \mathrm{km}^{2}$. Areas located further from the city, while maintaining a strong relationship with the city, mainly through home-to-work trips (alternating migrants, or commuters, living in these areas mainly work in the corresponding operational agglomeration), constituted the 'alternating migrants area'. Remaining areas were regrouped under the 'other areas' term and represent rural and less dense areas located far away from main city centres as well as secondary centres. Urban sprawl is linked to the suburbs and the alternating migrants areas (Brück, 2002). Finally, note that the influence of neighbouring countries and regions was not taken into account in Van der Haegen and Van Hecke's classification.

\subsection{The method}

A quantitative method was developed to assess the energy efficiency of home-to-work and home-to-school trips. The complete methodology and dataset are presented in detail by Marique and Reiter (2012a). This method uses empirical data from Belgium's national census, which is carried out every 10 years. One-day travel diary data collected from male and female heads of households were used from the two last surveys, respectively carried out in 1991 and 2001. For these households, information about demographics, socioeconomic status, car 
ownership, travel distances, the main mode of transportation used and the number of days worked per week and per person is available at the individual (desegregated) scale. These data are available for both home-to-work and home-to-school trips.

These data were also used by Boussauw and Witlox (2009) to develop a commute-energy performance index for Flanders and the Brussels capital region of Belgium. To build a locally specific index that is tailored to suburban areas, in addition to Boussauw and Witlox (2009) data, local characteristics of the public transport network in suburban areas (as significant differences exist between cities and suburban neighbourhoods), the type of vehicles used and the number of working days of the population in the neighbourhood were taken into account. In this paper, this method was applied to the entire regional territory to investigate the relationships between the spatial structure of the Walloon region of Belgium and the transport energy consumption for home-to-work and home-to-school trips.

Three indices are derived from this method. The energy performance index (expressed in $\mathrm{kWh} /$ travel per person) for a territorial unit represents the mean energy consumption for home-to-work/home-to-school trips for one worker/student living within a particular census block (district). This index takes into account the distances travelled, the means of transport used and their relative consumption rates, expressed by Equation 1. In the equation, $i$ represents the territorial unit; $m$ the mean of transport used (diesel car, petrol car, train, bus, bike, on foot); $D_{m i}$ the total distance travelled by means of transport $m$ in the district $i$ for home-to-work (or home-toschool) trips; $f_{m}$ the consumption factor attributed to means of transport $m$ and $T_{i}$ the number of workers (or students) in the territorial unit $i$.

1. Energy performance index $(i)=\frac{\sum_{m} D_{m i} \times f_{m}}{T_{i}}$

Consumption factors $f_{m}$ were calculated by Marique and Reiter (2012a) on the basis of regional and local data. Consumption factors are worth $0.56 \mathrm{kWh} /$ person per $\mathrm{km}$ for a diesel car, $0.61 \mathrm{kWh} /$ person per $\mathrm{km}$ for a petrol car, $0.45 \mathrm{kWh} /$ person per $\mathrm{km}$ for a bus, and 0 for non-motorised means of transportation because these do not consume any energy. The consumption factor for a train was recalculated, following Teller et al. (2010). It depends on the production of electricity as trains in Belgium are electric, and was calculated by dividing the total energy used to operate trains in Belgium by the total number of passengers per $\mathrm{km}$ in the reference year. The consumption factor for the train is worth $0.15 \mathrm{kWh} /$ person per $\mathrm{km}$. Note that this is a mean value that integrates both peak and off-peak hours.
The distance index (in $\mathrm{km}$ ) represents the mean distance travelled (one way) by one worker/student from home to work/school (see Equation 2).

2. Distance index $(i)=\frac{\sum_{m} D_{m i}}{T_{i}}$

The modal share index (in \%) represents the frequency of use for each mean of transportation per territorial unit, according to Equation 3, where $N D_{n}$ is the number of trips by mode $n$.

3. Modal share index mode $n(i)=\frac{N D_{n}}{\Sigma_{m} N D_{m}}$

Indices are calculated at three territorial scale: the census block (or district) scale, the former municipality scale and the municipality scale. In addition to these indices, the annual energy consumption for home-to-work (or home-to-school) trips is calculated according to Equation 4 , where $T D_{i}$ represents the total number of home-to-work (or home-to-school) trips (one way) for all the workers (or students) living within the territorial unit $i$. This factor takes into account the number of working days for each worker.

Annual energy consumption $(i)$

4. $=$ Energy performance index $i \times \mathrm{TD}_{i}$

Note that the unit of energy chosen to express the energy efficiency of home-to-work and home-to-school trips (kWh) was chosen to allow for a comparison between energy consumption in transport and energy consumption in the residential building sector (heating, appliances, electricity, etc.). This method is presented in Marique and Reiter (2012b).

\section{Spatial structure and energy consumption for home-to-work trips}

Figure 2 presents the energy performance index for home-towork trips, mapped at the municipality scale (2001 data) for the Walloon region of Belgium. At first glance, the general pattern of this map is similar to Van der Haegen and Van Hecke's urban type classification presented in Figure 1. The two main cities (operational agglomerations) of the region, Charleroi and Liège, show the lowest energy consumption rate (shown in white in Figure 2), whereas suburban and more rural or remote parts of the territory have a much higher energy consumption rate (shown in dark grey and black). The highest transport energy consumption levels are found in two suburban parts of the region: the Brabant wallon (in the north) and the area south of Luxembourg province (in the south). These two areas have strong relationships with the metropolitan area of Brussels and Luxembourg city, respectively, due to the high 


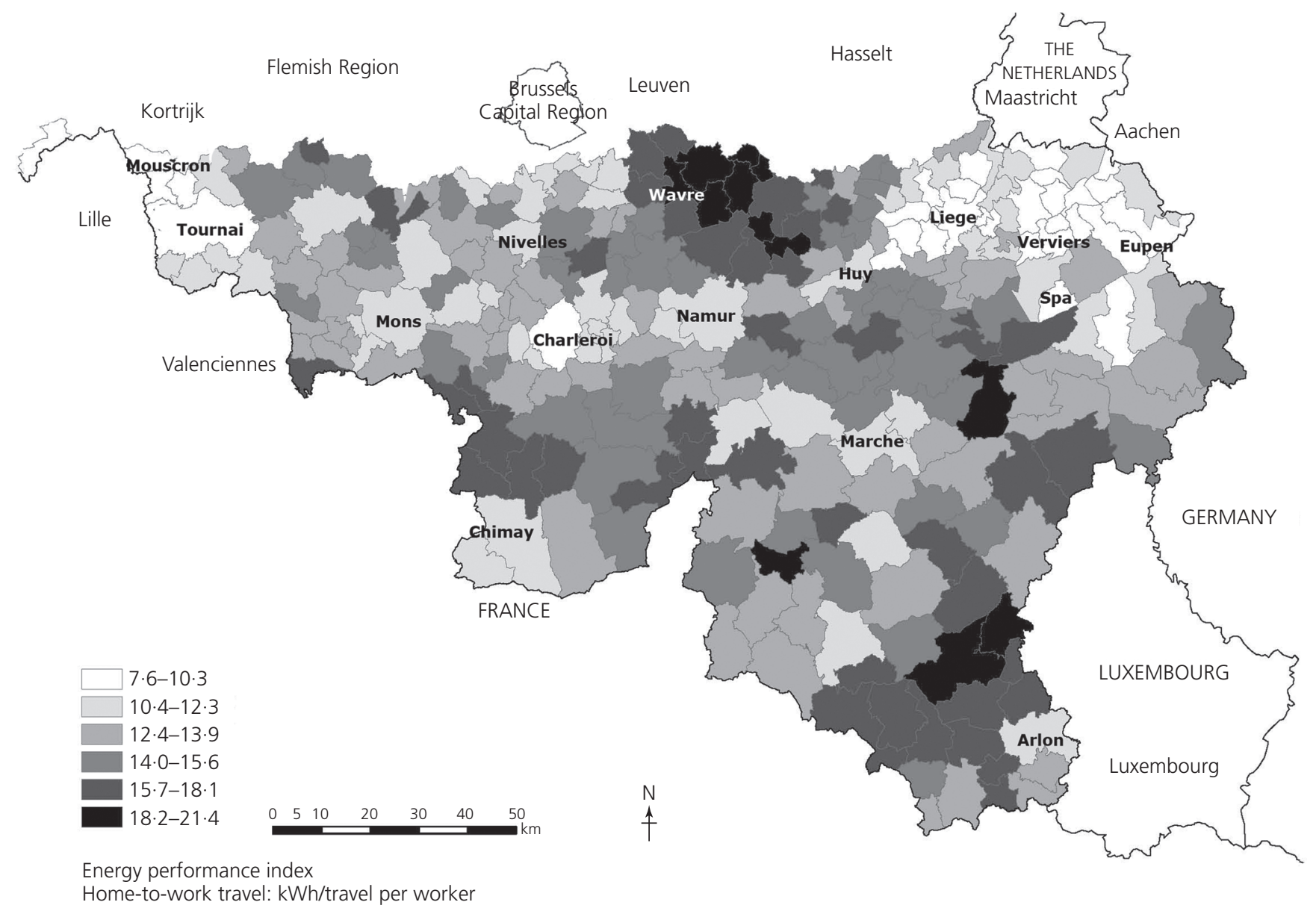

Figure 2. Energy performance index for home-to-work trips (in KWh/travel per worker) at the municipality scale; data: 2001

concentration of employment in these cities. However, the price of land close to these cities is relatively high, which encourages workers to live in remote suburban neighbourhoods and commute longer distances to their places of work. Moreover, public transportation is generally less available in these low-density developments, which results in a higher modal share of the private car.

Table 1 gives the mean value of the energy performance index $(\mathrm{kWh} /$ travel per worker) for the three urban types and for the

\begin{tabular}{|c|c|c|c|}
\hline & $\begin{array}{l}\text { Operational } \\
\text { agglomerations }\end{array}$ & Suburbs & $\begin{array}{l}\text { Alternating } \\
\text { migrants areas }\end{array}$ \\
\hline Mean energy performance index: kWh/travel per worker & $10 \cdot 4$ & $12 \cdot 9$ & $14 \cdot 2$ \\
\hline Brussels (only the part located in the Walloon region, does not include the CBD) & $11 \cdot 5$ & $12 \cdot 7$ & $15 \cdot 1$ \\
\hline Charleroi & $10 \cdot 3$ & $13 \cdot 5$ & $13 \cdot 9$ \\
\hline Liège & $9 \cdot 4$ & $12 \cdot 7$ & $14 \cdot 0$ \\
\hline Mons & $12 \cdot 2$ & $12 \cdot 9$ & $12 \cdot 0$ \\
\hline Namur & $10 \cdot 8$ & $13 \cdot 8$ & $14 \cdot 2$ \\
\hline Mean distance for one trip: $\mathrm{km}$ & $21 \cdot 3$ & $25 \cdot 5$ & $29 \cdot 5$ \\
\hline Mean modal share (bus): \% & 4.0 & 1.7 & 1.5 \\
\hline Mean modal share (train): \% & $14 \cdot 0$ & $12 \cdot 7$ & $15 \cdot 4$ \\
\hline
\end{tabular}




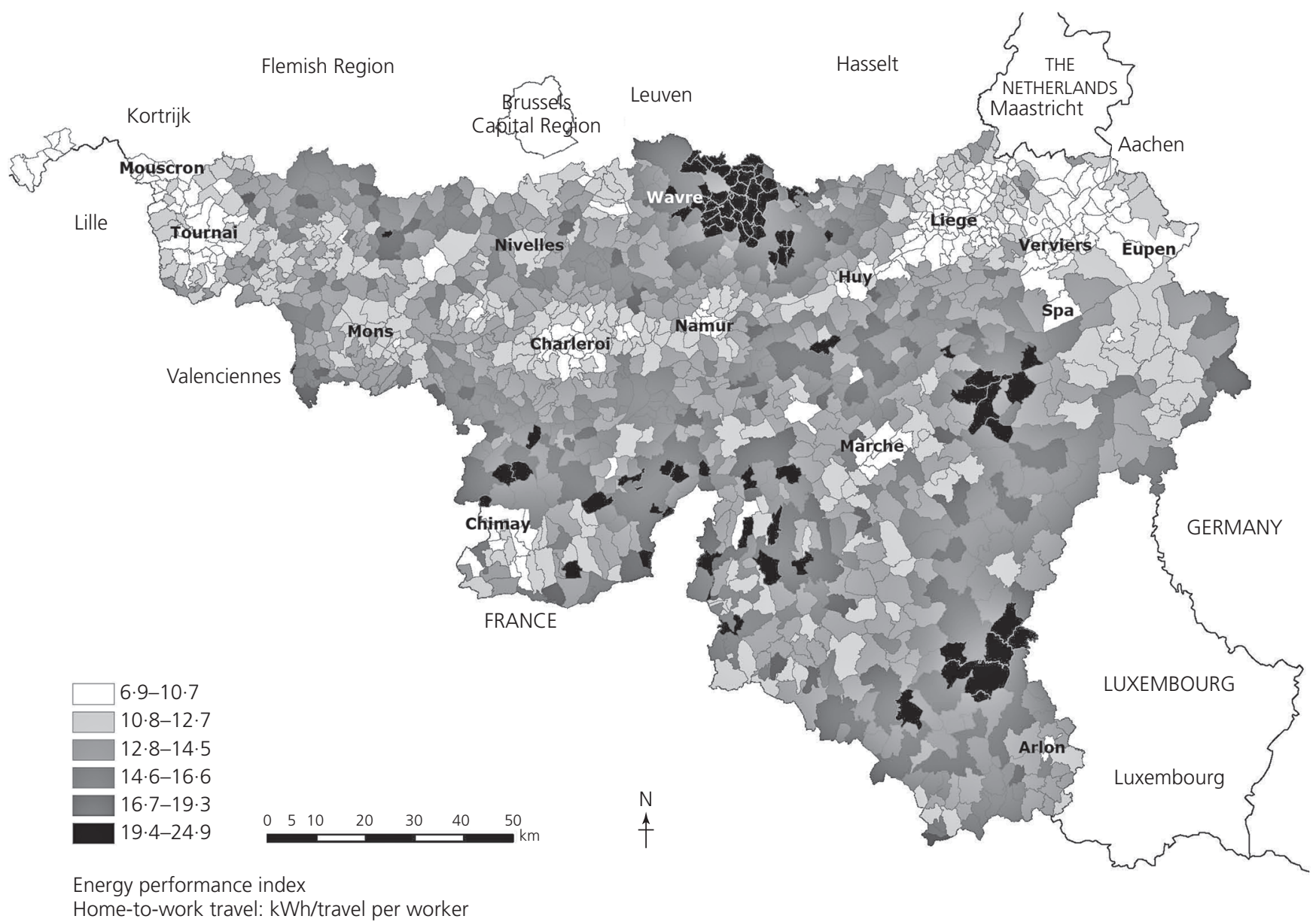

Figure 3. Energy performance index for home-to-work trips (in KWh/travel per worker) at the former municipality scale; data: 2001

five largest cities of the region. Note that Brussels does not belong to the Walloon region, but many workers working in

Q6 this city live in the Walloon region (see Figure 1). Table 1 highlights that transport energy consumption rises with the distance to city centres where much of the employment is concentrated. Travelled distances were also calculated for the three main urban types. These distances are shorter in operational agglomerations, compared to the areas with less density. The modal share of the bus is higher in the operational agglomerations, whereas the modal share of the train is similar in the three areas. Note that the policy of the Belgian national railway society tends to close stations located in small towns and to reorganise its services around main stations and lines from west to east (Lille-Aachen, along the old industrial basin where many residents and jobs are concentrated) and from south to north (Luxembourg-Brussels).

Calculating and mapping the energy performance index for home-to-work commutes at the former municipality scale
(Figure 3) and the local scale refines these initial observations. Outside the main agglomerations, several secondary municipalities and settlements (census blocks or districts) also show lower consumption rates. Most of these are cities and neighbourhoods that are located along the old industrial basin (from west to east: Mouscron, Tournai, Mons, Charleroi, Namur, Huy, Liège, Verviers and Eupen), or smaller towns in the southern, less densely populated part of the Walloon region (Chimay, Marche, Spa and Arlon). These secondary settlements are located outside the influence of the main regional cities. Population density is low, and people typically manage to find employment locally. This local-scale approach thus highlights more local phenomena linked to the location of secondary employment centres in areas located far from major cities.

In conclusion, two distinct phenomena co-exist: 'metropolisation' and 'territorial recomposition'. Metropolisation induces higher commuting distances in the suburbs of attractive metropolises (such as Luxembourg and Brussels or, to a lesser extent, 


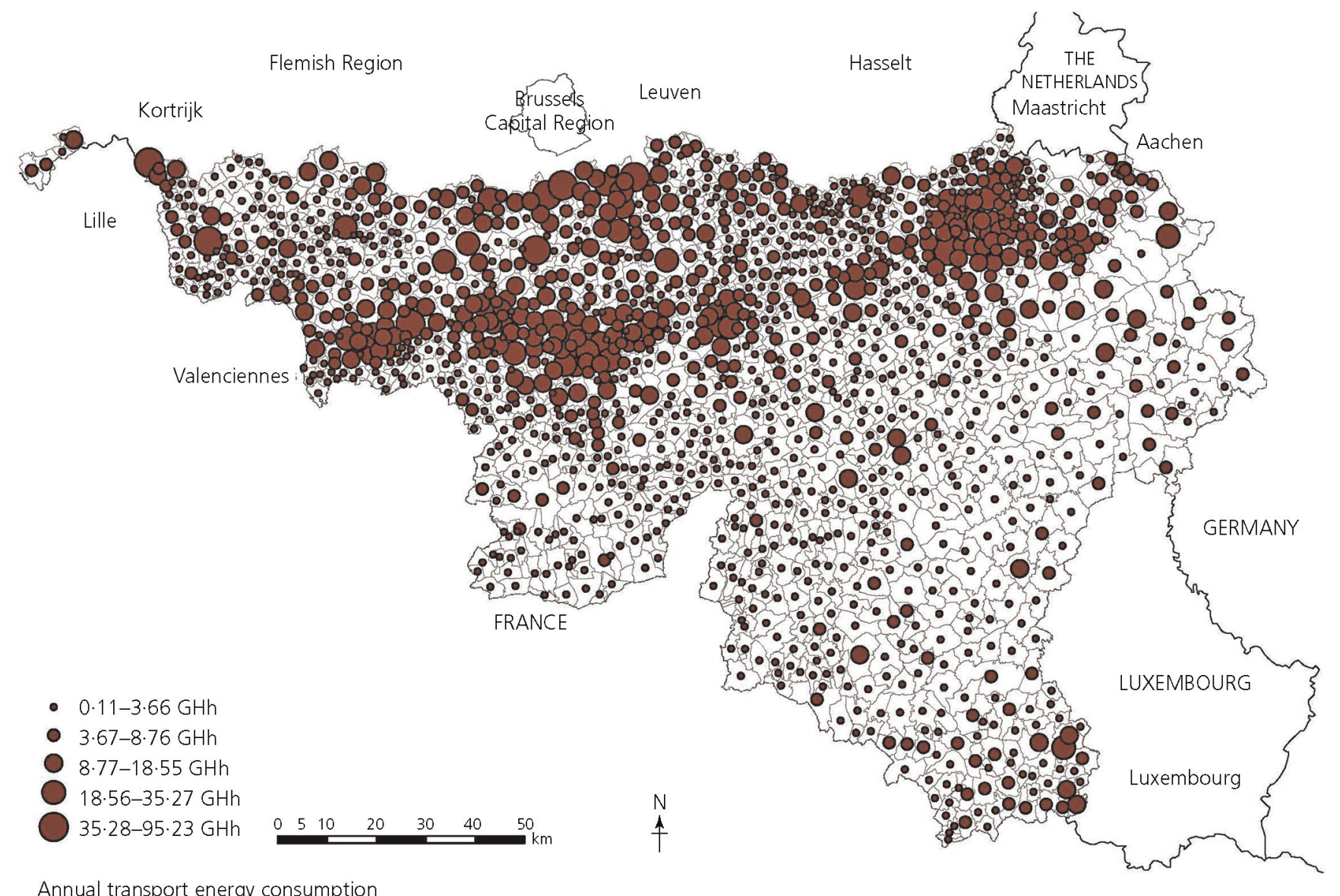

Annual transport energy consumption Home-to-school travel: GWh

Figure 4. Annual transport energy consumption for home-to-work trips per former municipality; data: 2001

Lille (in France) and Aachen (in Germany)) where employment is concentrated. Note that these poles are all located outside the Walloon region of Belgium, and three metropolises are located outside of Belgium very close to its border. The influence area of these poles can reach 40 or $50 \mathrm{~km}$. The territorial recomposition occurs mainly in the north part of the region (Brabant wallon) in the suburbs of Brussels. Secondary employment centres were developed over the past few years and allow the local population that used to travel to Brussels for work to find work closer to their homes instead. This allows for shorter commuting distances and thus lower scores for the local energy performance index. In the case of territorial recomposition, the suburbanisation of housing is accompanied by a local re-concentration of employment.

The annual transport energy consumption for home-to-work trips per former municipality is mapped in Figure 4. The observations made for the energy performance index are inverted. Former municipalities with high transport energy consumption are strongly linked with areas with high-density population and highlight the importance of these areas in terms of potential energy savings. The population affected by the energy savings measures undertaken in those areas is particularly large. The total annual energy consumption for home-to-work trips in the entire region amounts to $6804 \mathrm{GWh}$.

\section{Comparison with home-to-school trips}

The method developed in Marique and Reiter (2012a) also allows for discussion of the energy efficiency of home-toschool trips, as data relating to these types of trips are available in the national census. Observations regarding the relation between transport energy consumption and the urban structure drawn for home-to-work trips, at the three territorial scales, are also valid for home-to-school trips: lowest energy performance indices are found in dense urban former municipalities and settlements, located along the former industrial basin (Figure 5). However, home-to-school trips consume much less energy per capita and per travel than home-to-work trips, as 


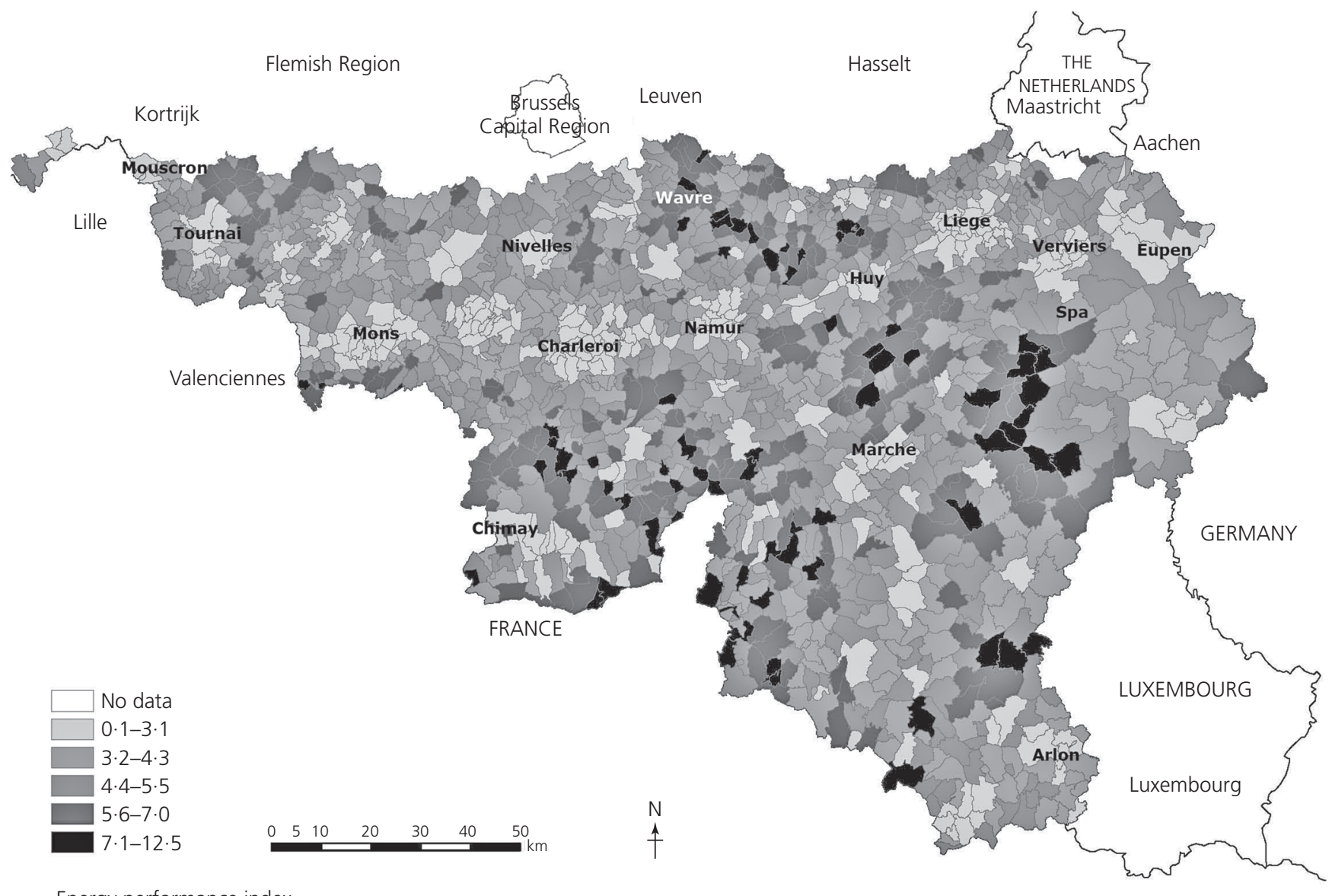

Energy performance index

Home-to-school travel: kWh/travel per student

Figure 5. Energy performance index ( $\mathrm{kWh} /$ travel per student) for home-to-school travels; data: 2001

shown in Table 2. For example, in 2001, the mean energy performance index for home-to-school trips is worth $3.5 \mathrm{kWh} /$ travel per student, while the mean energy performance index for home-to-work trips was worth $12.1 \mathrm{kWh} /$ travel per worker. The main explanation for this observation is that schools are spread throughout the entire regional territory, even in the most rural municipalities (rural core, suburban centres, etc., are equipped with at least one primary school). This allows for reduced distances from the homes to destinations, whereas work locations remain concentrated in main cities or suburban business centres. For example, the mean distance travelled from home to work is $24 \mathrm{~km}$, and the mean distance travelled from home to school is $8.2 \mathrm{~km}$.

In terms of modal shares, significant differences are highlighted: the use of non-motorised means of transportation (bicycle, on foot) is much higher for home-to-school trips (14.7\%) than for home-to-work trips $(4.7 \%)$. The bus is more often used to go to school $(21.8 \%$ ) than to work (only $2.3 \%$ ), whereas the use of the train is more or less equivalent for these two types

\begin{tabular}{llrr}
\hline & Operational agglomerations & Suburbs & Alternating migrants areas \\
\hline Mean performance index: $\mathrm{kWh}$ /travel per student & $2 \cdot 7$ & $4 \cdot 2$ & $4 \cdot 2$ \\
Mean distance for one trip: $\mathrm{km}$ & $7 \cdot 6$ & $11 \cdot 1$ & $11 \cdot 2$ \\
Table 2. Indices for home-to-school travel (data: 2001) & & \\
\hline
\end{tabular}




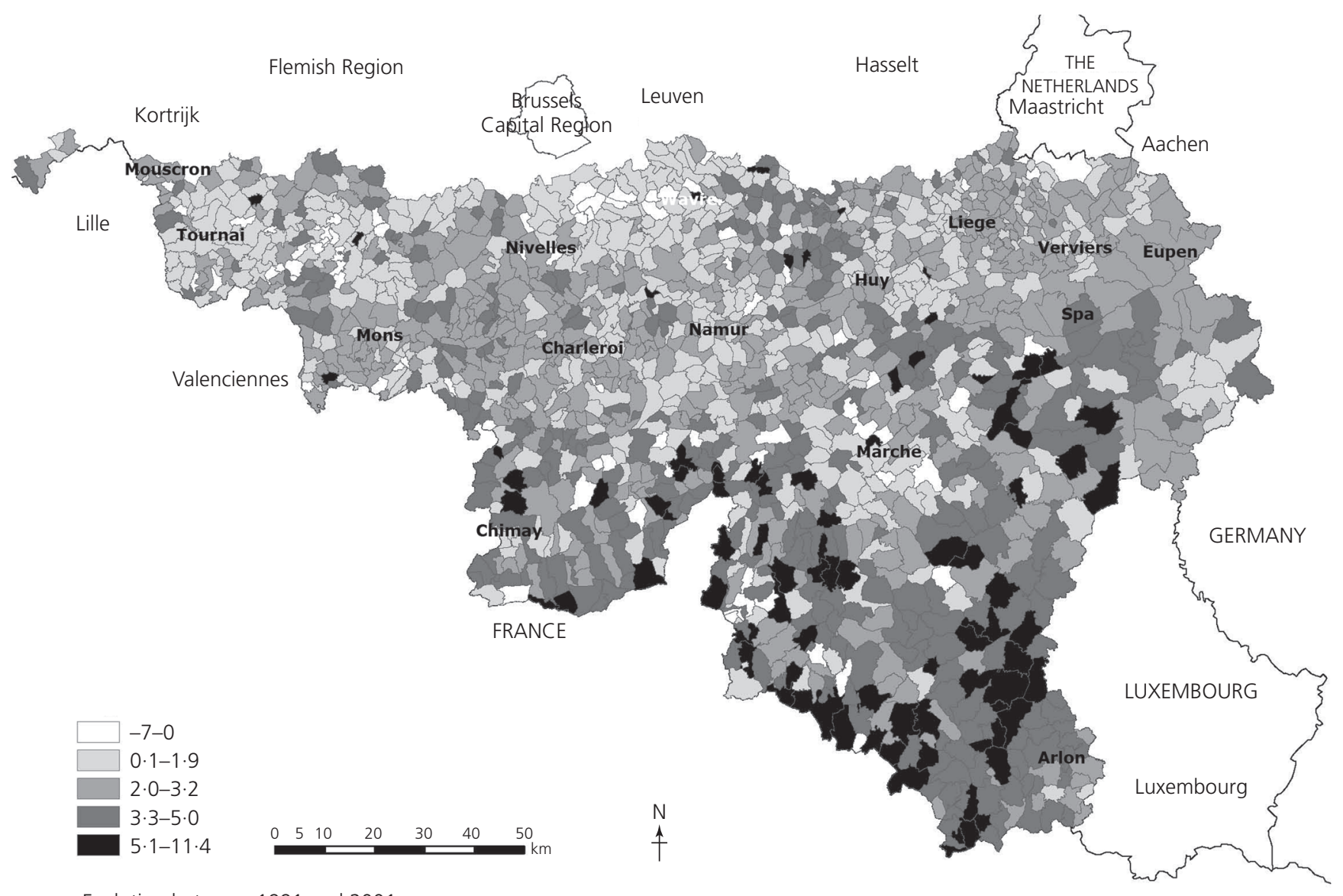

Evolution between 1991 and 2001

Home-to-work travel: kWh/travel per worker

Figure 6. Difference (kWh/travel per worker) between performance indices for home-to-work trips at the former municipality scale in 2001 and in 1991

of commutes ( $6 \%$ for home-to-work and $7.6 \%$ for home-toschool trips). The car is the favourite means of transportation for both purposes, with $85.2 \%$ for home-to-work trips and $55.8 \%$ for home-to-school trips. Furthermore, use of the car is greater in suburban areas than in central urban areas.

\section{The evolution between 1991 and 2001}

The evolution of the energy performance index between 1991 and 2001 was calculated for home-to-work trips and is mapped in Figure 6. A significant increase in transport energy consumption is highlighted in most former municipalities. This increase is particularly large in the south of the region (the area in relation to the metropolitan area of Luxembourg city). Many low-density suburban neighbourhoods were developed in this area over the past decade to accommodate the rising number of people that were working in Luxembourg but were not able to pay Luxembourg prices for accommodation (Vanneste et al., 2007). These municipalities often have plenty of building land available at low prices (which is not the case in Luxembourg) but do not offer enough employment opportunities. The annual transport energy consumption for home-to-work trips was worth $5017 \mathrm{GWh}$ in 1991, amounting to an increase of $26 \cdot 2 \%$ between 1991 and 2001 . The evolution of the annual transport energy consumption for home-to-school trips follows the same trend, with an increase of $23 \%$, even if the annual energy consumption is lower overall (589 GWh in 1991 and $766 \mathrm{GWh}$ in 2001). The use of the private car has increased for both purposes of travel $(+5.2 \%$ for home-to-work and $+11.6 \%$ for home-to-school trips) to the detriment of nonmotorised modes of transport and buses.

\section{Main parameters}

The general pattern of the energy performance index map is very similar to the map presenting the mean travelled distance (see Figure 7 for home-to-work trips). The energy efficiency of home-to-work and home-to-school trips is strongly determined 


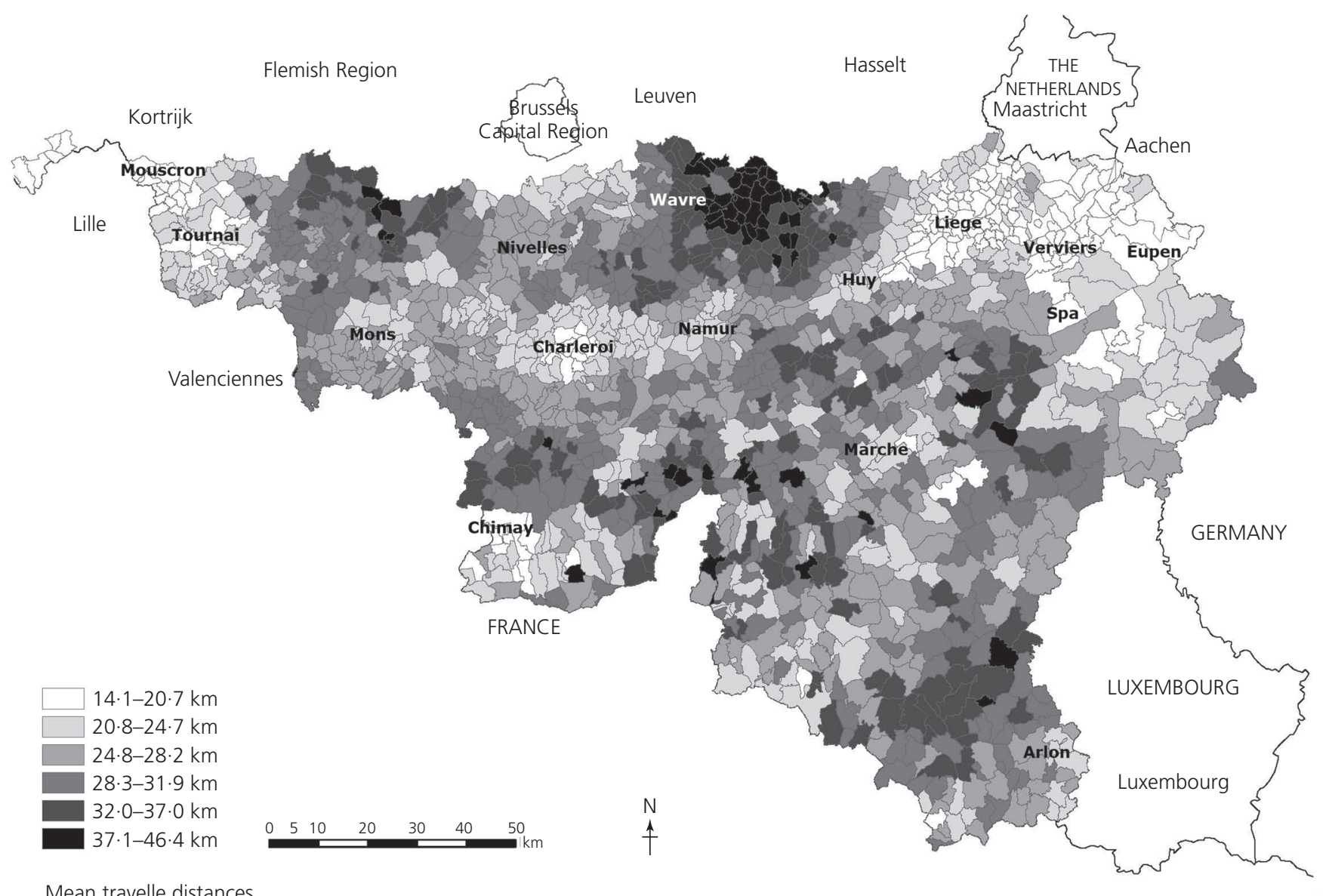

Mean travelle distances

Home-to-work travel: km

Figure 7. Mean travelled distances from home to work (in km) at the former municipality scale in 2001

by the distance travelled. Mode choice has less of an impact on the energy performance of those types of commutes. This can partly be explained by the relationship between distance and mode choice. The consumption factor used for the train is approximately four times lower than the consumption factors used for a private car, but trips by train are much longer than trip by car. The location of activities and a mix of functions at the living area scale are thus important strategies for promoting a reduction in transport energy consumption. Promoting more efficient public transportation in these areas could also be a credible strategy for two reasons: more energy-efficient vehicles and a better occupation rate could both reduce the consumption factor for the bus.

\section{Discussion}

Several limitations of the proposed method must be acknowledged. First of all, the factors used to convert kilometres for each mode of transportation into $\mathrm{kWh}$ are calculated for the entire territory (including urban and rural areas). Factors used for public transport are found to be slightly unfavourable compared to urban centres. This is explained by the reduced consumption factor per person and per kilometre in urban centres because the occupancy rate of public transport is higher. Moreover, congestion in city centres and above-average speeds on non-congested motorways, which can lead to higher energy consumption rates and vehicle emissions (Beevers and Carlslaw, 2005; Department for Transport, 2011; Den Tonkelaar,1994) are not considered.

Second, even if many studies dedicated to transport and energy consumption only focus on home-to-work data because they are the most often available, a limitation of the method arises because data on only two types of trips (home-to-work and home-to-school journeys) are available in national censuses. Those types of journeys are not representative of all trips made by a household even if they play a major role in them because they are commuting journeys and significantly affect related trips for leisure or commercial purposes. 'Type-profiles', 
such as those performed on smaller areas by Saunders et al. (2008), could be developed to take into account those trips in further research.

Third, although the calculations of the indices lead to quantitative results, analyses are mainly based on visual inspections of the maps to link the spatial structure of the territory and transport energy consumption, at different scales. Note that the quantitative data are necessary and that visual analysis alone can lead to misinterpretations of the results. To strengthen the qualitative visual analysis, complementary quantitative methods and techniques could be explored in further analyses. Multivariate regression analyses performed by Marique et al. (2012)

Q8 for home-to-school trips confirm the qualitative findings highlighted through a qualitative assessment of map patterns

Finally, it should be mentioned that the structure of a territory is not the only parameter that influences energy consumption for commuting. The analyses presented in this paper did not take into account external factors, such as income levels, improvements in the vehicles, behaviours and lifestyles of the commuters, etc., although the authors still believe these factors may influence adult mobility behaviours. Due to the huge inertia of the urban structure and market forces (in particular in neighbouring Luxembourg), major changes in the location of work places and residences can only be considered in the long term. Land use policies should mainly favour the reduction of distances through a better mix of functions, at the living area scale, in areas with large concentrations of the local population, and be more directive as far as the location of new work places and residences is concerned. In addition to the results presented in this paper, more efficient vehicles, alternative technologies (e.g. hybrid electric vehicles supplied by low-carbon electricity, and supported, favourable tax and local charging regimes (Gibbins et al., 2007), hybrid trains that uses batteries as an energy storage device (Wen et al., 2007)) and more sustainable behaviours and lifestyles related to transportation should also be encouraged effectively to reduce transport energy consumption and GHG emissions.

As far as the reproducibility of this approach is concerned, the method is parameterised and, if the same type of empirical survey data exist, they can be reproduced for other territories by adjusting parameters for vehicles, consumption factors, etc.

\section{Conclusions and perspectives}

Using a quantitative method developed to evaluate transport energy consumption and its application to the Walloon region of Belgium, this paper has shown that urban structure (that is to say, the system defined by the location of work places and services, the spatial distribution of population according to residence and infrastructures), acts on travel energy consumption. This study also questioned the issue of scale through an evaluation of the energy efficiency of home-to-work and home-to-school trips at several territorial scales. This study has shown that a local-scale approach is useful, as it allows for a more nuanced picture of the energy performance of commuting in urban and suburban areas. The local-scale approach highlights local phenomena, particularly the existence of secondary urban cores characterised by low energy consumption inside suburban territories due to the local re-concentration of employment opportunities and a sufficiently large concentration of local population. Two distinct phenomena were highlighted: 'metropolisation', which results in a longer commuting distance in the suburbs to major employment centres (such as Luxembourg and Brussels), and 'territorial recomposition', which tends to reduce travelled distances inside suburban or remote territories. In this respect, the current mobility policies should be more context specific by also addressing the sustainability of transport at the local scale.

\section{Acknowledgements}

This research is funded by the Walloon region of Belgium in the framework of the suburban areas favouring energy efficiency project (SAFE).

\section{REFERENCES}

Banister D (1992) Energy use, transport and settlement patterns. In Sustainable Development and Urban Form (Breheny M (ed.)). Pion Ltd, London, UK, pp. 160-181.

Beevers SD and Carslaw DC (2005) The impact of congestion charging on vehicle speed and its implications for assessing vehicle emissions. Atmospheric Environment 39(x): 6875-6884.

Berry B and Okulicz-Kozaryn A (2009) Dissatisfaction with city life: a new look at some old questions. Cities 26(x): 117-124.

Boarnet M and Crane R (2001) The influence of land use on travel behaviour: specification and estimation strategies. Transportation Research Part A: Policy and Practice 35(9): 823-845.

Boussauw K and Witlox F (2009) Introducing a commuteenergy performance index for Flanders. Transportation Research Part A 43(x): 580-591.

Breheny MJ and Gordon IR (1997) Urban densities, travel behavior and the limits to planning. Proceedings of BEPAC/EPSRC Conference on Sustainable Buildings, Abingdon, UK, pp. 37-42.

Brück L (2002) La périurbanisation en Belgique. University of Liège, SEGEFA, Liège, Belgium (in French).

Couch C and Karecha J (2006) Controlling urban sprawl: some experiences from Liverpool. Cities 23(5): 353-363.

da Silva ANR, Costa GCF and Brondino NCM (2007) Urban sprawl and energy use for transportation in the largest Brazilian cities. Energy for Sustainable Development 11(3): 44-50. 
Den Tonkelaar WAM (1994) Effects of motorway speed limits on fuel consumption and emissions. Science of the Total

Environment 146-147(x): 201-207.

Department for Transport (2011) Values of Time and Operating Costs. Transport Analysis Guidance (TAG) Unit 3.5.6, London, UK.

Dujardin S, Boussauw K, Brévers F et al. (2011) Home-towork commuting, spatial structure and energy consumption: comparative analysis of Wallonia and Flanders. Proceedings of the BIVEC/GIBET Transportation Research Day (Cornelis E (ed)). University Press BVBA, Namur, Belgium, pp. 1-14.

European Commission (2008) European Energy and transport

Q10 - trends to 2030. European Commission.

European Environment Agency (2006) Urban sprawl in Europe. The ignored challenge. Office for Official Publications of the European Communities, Luxembourg, Report 10/2006, pp. 1-56.

Ewing RH (1994) Characteristics, causes and effects of sprawl: a literature review. Environmental and Urban Studies 21(x): Q9 1-15.

Ewing RH and Cervero R (2001) Travel and the built environment: a synthesis. Transportation Research Record 1780: $87-114$.

Ewing RH and Cervero R (2010) Travel and the built environment: a meta-analysis. Journal of the American Planning Association 76(3): 265-294.

Ewing R, Bartholomew K, Winkelman S, Walters J and Chen D (2008) Growing Cooler: The Evidence on Urban Development and Climate Change. Urban Land Institute, Washington DC, USA.

Gibbins J, Beaudet A, Chalmer H and Lamperth M (2007) Electric vehicles for low-carbon transport. Proceedings of the Institution of Civil Engineers - Energy 160(4): 165-173.

Gilbert R and Perl A (2008) Transport Revolutions: Moving People and Freight Without Oil. Earthscan, London, UK.

Gillham O (2002) The Limitless City: A Premier on the Urban Sprawl Debate. Island Press, Washington DC, USA.

Glicksman LR (2007) Editorial: The energy crisis - the need for more balanced solutions. HVAC\&R Research Journal 4(x): 521-523.

Gordon P and Richardson H (1997) Are compact cities a desirable planning goal? Journal of the American Planning Association 63(1): 95-106.

Graham A (2000) Demand for leisure air travel and limits to

Q9 growth. Journal of Air Transport Management 6(x): 109-118.

Halleux JM, Brück L and Mairy N (2002) La périurbanisation résidentielle en Belgique à la lumière des contextes Suisse et Danois: enracinement, dynamiques centrifuges et

Q9 régulations collectives. BELGEO 4(x): 333-354 (in French).

Howley P (2009) Attitudes towards compact city living: towards a greater understanding of residential behavior.
Hubert JP (2004) Mobilité urbaine, périurbaine, rurale en Belgique: où sont les différences? Les Cahiers Scientifiques du Transport 45(x): 83-100 (in French).

Lavadinho S and Lensel B (2010) Importons la notion de centralité en périphérie: pour une soutenable émergence de la qualité urbaine dans la Zwischenstadt. Urbia 11(x): 113-143 (in French).

Marique AF and Reiter S (2012a) A method for evaluating transport energy consumption in suburban areas. Environmental Impact Assessment Review 33(x): 1-6.

Marique AF and Reiter S (2012b) A method to evaluate the energy consumption of suburban neighbourhoods. HVAC\&R Research Journal 18(1-2): 88-99.

Marique AF, Dujardin S, Teller J and Reiter S (2012) School commuting: the relationship between energy consumption and urban form. Journal of Transport Geography in press.

Neuman M (2005) The compact city fallacy. Journal of Planning Education and Research 25(x): 11-26.

Newman P and Kenworthy JR (1999) Sustainability and Cities: Overcoming Automobile Dependence. Island Press, Washington, USA.

OECD and IEA (Organisation for Economic Co-operation and Development and International Energy Agency) (2008) World Energy Outlook 2008. International Energy Agency, Paris, France.

Owens S (1986) Energy, Planning, and Urban Form. Pion, London, UK.

Pisarski AE (2006) Commuting in America III. Transportation Research Board, Washington DC, USA.

Saunders MJ, Kuhnimhof T, Chlond B and da Silva ANR (2008) Incorporating transport energy into urban planning. Transportation Research Part A 42(x): 874-882.

Souche $S$ (2010) Measuring the structural determinants of urban travel demand. Transport Policy 17(x): 127-134.

Sporck JA, Van der Haegen H and Pattyns M (1985) L'organisation spatiale de l'espace urbain. La cité belge d'aujourd'hui, quel devenir? Bulletin Trimestriel Crédit Communal de Belgique 154(x): 153-164 (in French).

Steemers K (2003) Energy and the city: density, buildings and transport. Energy and Building 35(1): 3-14.

Teller J, Dujardin S, Labeeuw FL, Melin E and Pirart F (2010) Structuration du territoire pour répondre aux objectifs de réduction des émissions de gaz à effet de serre Rapport CPDT 2010, pp. 1-166 (in French).

Urban Task Force (1999) Towards an Urban Renaissance. Urban Task Force, Routledge, London, UK.

Van de Coevering P and Schwanen T (2006) Re-evaluating the impact of urban form on travel patterns in Europe and North America. Transport Policy 13(x): 229-239.

Van der Haegen H, Van Hecke E and Juchtmans G (1996) Les regions urbaines Belges en 1991. Etudes statistiques de l'INS, Report INS 104. 
Energy

Volume 166 Issue ENO
Urban sprawl, commuting and travel

energy consumption

Marique, Dujardin, Teller and Reiter
Vanneste D, Thomas I and Goossens L (2007) Woning en Woonomgeving in Belgie. SPF Economy and Statistics, Q13 SPT Scientific Policy, Brussels, Belgium (in Dutch). Van Wee B (2002) Land use and transport: research and policy challenges. Journal of Transport Geography 10(x): 259-271.
Wen Q, Kingsley S and Smith RA (2007) Energy simulation of hybrid inter-city trains. Proceedings of the Institution of Civil Engineers - Energy 160(3): 123-131.

\section{WHAT DO YOU THINK?}

To discuss this paper, please email up to 500 words to the editor at journals@ice.org.uk. Your contribution will be forwarded to the author(s) for a reply and, if considered appropriate by the editorial panel, will be published as a discussion in a future issue of the journal.

Proceedings journals rely entirely on contributions sent in by civil engineering professionals, academics and students. Papers should be 2000-5000 words long (briefing papers should be 1000-2000 words long), with adequate illustrations and references. You can submit your paper online via www.icevirtuallibrary.com/content/journals, where you will also find detailed author guidelines. 


\section{Journal query sheet}

\begin{tabular}{|l|l|}
\hline Journal: Energy & Volume/issue \\
\hline Authors: Marique, Dujardin, Teller and Reiter & Reference No: EN1200002 \\
\hline Title: Urban sprawl, commuting and travel energy consumption & \\
\hline
\end{tabular}

Queries are identified by manuscript page and line number of original or paragraph and section. Often it is easier to count upwards from the foot of the page; such numbers are annotated 'up'.

\begin{tabular}{|c|c|}
\hline No. & Query \\
\hline 1 & $\begin{array}{l}\text { Please select up to three keywords from the official ICE list (available at http://www.icevirtuallibrary.com/upload/ } \\
\text { proceedingskeywords.pdf) }\end{array}$ \\
\hline 2 & Please provide post-nominal qualifications for the first author \\
\hline 3 & Please provide post-nominal qualifications for the second author \\
\hline 4 & Please spell out IUTP here \\
\hline 5 & The in-text citation of Equation 2 has been added here - please confirm this is OK \\
\hline 6 & Figure 1 is in black and white, therefore there is no 'yellow part' please clarify how this should be explained \\
\hline 7 & Please check the meaning of the sentence: 'Those types of journeys . . . for leisure or commercial purposes.' \\
\hline 8 & $\begin{array}{l}\text { Has the Marique reference (originally cited as 'in press') been accepted for publication? If so, please amend the year, } \\
\text { if necessary }\end{array}$ \\
\hline 9 & Please provide the issue number if there is one \\
\hline 10 & Please provide location of publisher European Commission \\
\hline 11 & $\begin{array}{l}\text { See note } 8 \text { - if this reference has been accepted for publication please correct the year of publication, if necessary. If it } \\
\text { has not been accepted for publication please remove from the reference list and cite in full in the text }\end{array}$ \\
\hline 12 & Please provide details of the publisher and their location \\
\hline 13 & Is Dutch the correct language here? \\
\hline
\end{tabular}

